\title{
Akutní proximální aortální disekce penetrujíci do levé sině, řešená urgentní Bentallovou operací
}

Prezentujeme průběh onemocnění u 42letého pacienta, který byl odeslán na naše pracoviště ze spádového interního oddělení pro intermitentní, asi týden trvající klidové bolesti na hrudi pro suspekci na akutní koronární syndrom s elevacemi segmentu ST v oblasti spodní stěny. Provedena koronarografie s negativním nálezem na věnčitých tepnách, ventrikulografie (RLVG) bez regionální poruchy kinetiky levé komory srdeční, ejekční frakce levé komory (EF LK) 65\%.

Bylo doplněno transthorakální echokardiografické vyšetření $\mathrm{s}$ nálezem kulovitého útvaru o velikosti zhruba $35 \times 35 \mathrm{~mm}$, který se projikoval do oblasti síňového septa. Ascendentní aorta a aortální chlopeň

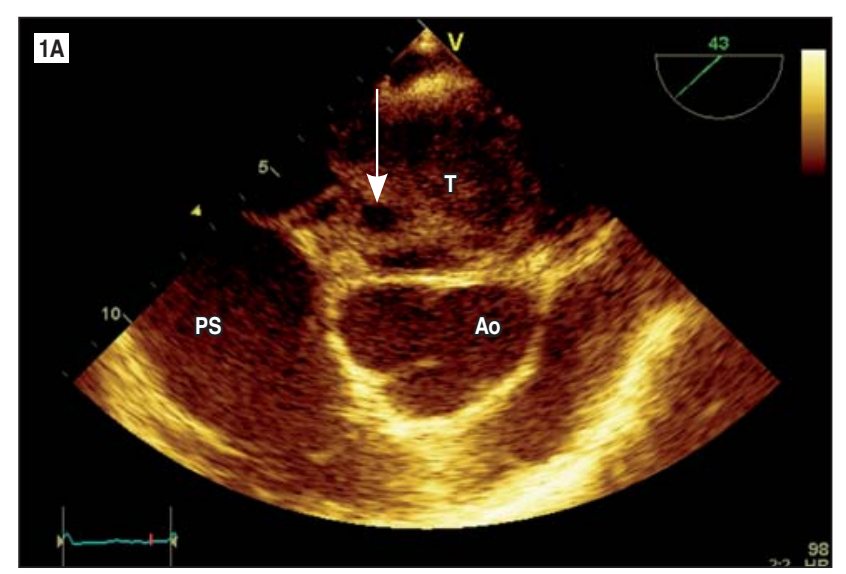

nebyly transthorakálně dobře přehledné, proto bylo doplněno, i vzhledem $\mathrm{k}$ marfanoidnímu habitu pacienta, transesofageální echokardiografické vyšetření (TEE).

V oblasti ascendentní aorty bylo při TEE (obrázek 1) vidět akutně disekované aneurysma ascendentní aorty s patrným objemným falešným lumen, které bylo vyplněno hyperechogenními hmotami charakteru trombu. Dále byl zřetelný vysokorychlostní tok z penetrace falešného lumen aortální disekce do stropu levé síně s patrným asi $2,5 \mathrm{~cm}$ dlouhým pendulujícím laločnatým útvarem, který byl evidentně v lumen levé síně. Disekce byla při TEE patrna až do distální descendentní hrudní aorty.

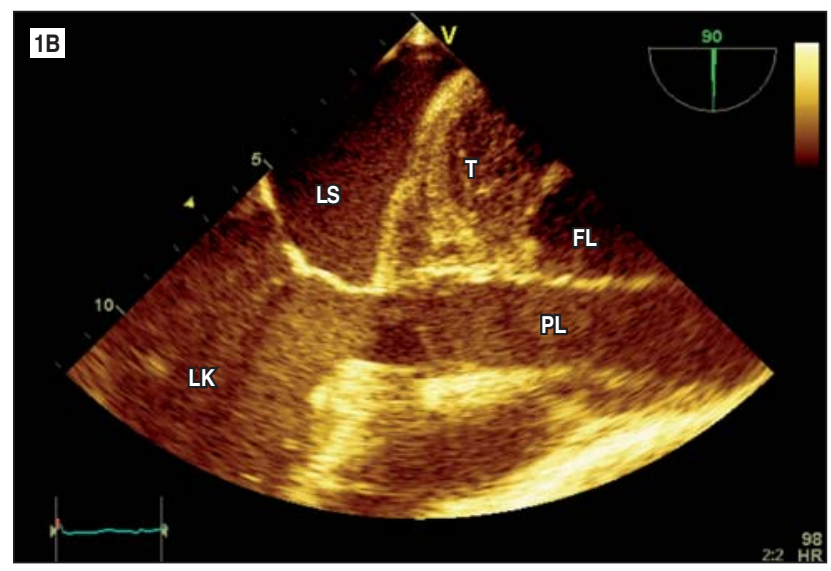

Obr. 1 Transesofageální vyšetření

A. V midesofageální projekci TEE na krátkou osu v úrovni aortální chlopně je patrna disekce a trojcípá aortální chlopeň (Ao). Ve falešném lumen je dále evidentní trombus (T) $\mathrm{s}$ anechogenním penetračním kanálem (šipka), směřující do levé síně (LS).

B. Midesofageální projekce na dlouhou osu aortální disekce zobrazuje pravé lumen (PL) a falešné lumen (FL) ascendentní aorty.

PS - pravá síň, LK - levá komora, FL - falešné lumen

Marián Benčat, Martin Hutyra*, Vladimír Lonský, Jan Václavík*, Josef Novotný**, Jan Lukl*

Kardiochirurgická klinika, *I. interní klinika, Fakultní nemocnice Olomouc a Lékařská fakulta Univerzity Palackého, **Radiodiagnostické oddělení, Vojenská nemocnice Olomouc, Olomouc, Česká republika

Adresa: MUDr. Marián Benčat, Kardiochirurgická klinika, FN Olomouc a LF UP, I. P. Pavlova 6, 77520 Olomouc, Česká republika, e-mail: marianbencat@seznam.cz 
CT angiografie aorty (obrázek 2) potvrdila diagnózu stanovenou při TEE vyšetření. Šlo o nález rozsáhlého disekujícího aneurysmatu hrudní aorty s intimálním pruhem oddělujícím falešné a pravé lumen prakticky v celém průběhu kontrastně naplněné aorty. Distální konec disekce byl patrný na aneurysmaticky rozšířené vinuté arteria iliaca communis dextra.
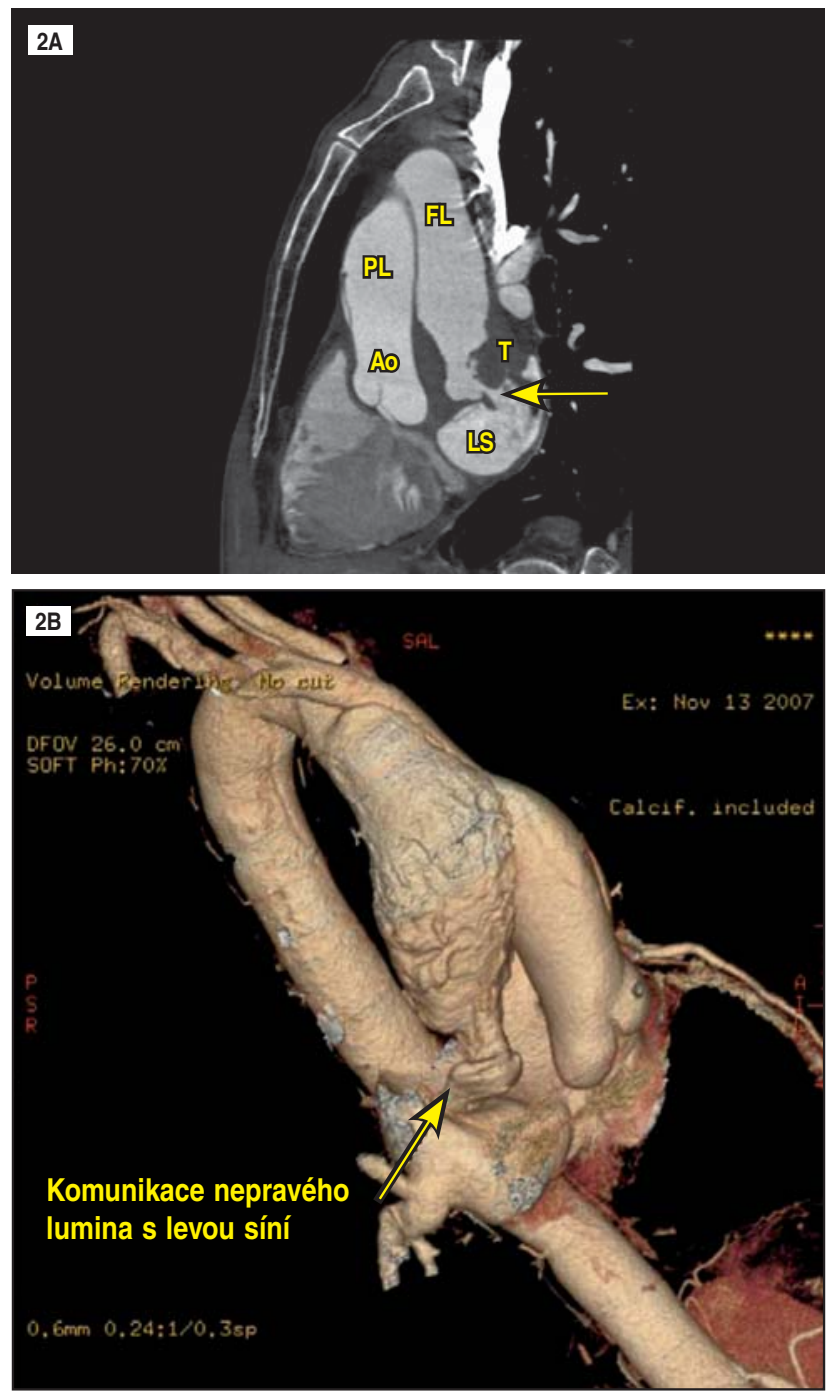

Obr. 2 CT angiografie aorty

A. V uvedené projekci je evidentní retrosternálně lokalizovaná rozsáhlá disekce aneurysmatu hrudní aorty (Ao) s nálezem penetrace do levé síně (LS), šipka. Dále je patrna intimální linie oddělující pravé aortální lumen (PL) od falešného (FL). Hyposignální hmoty s nepravidelnými okraji lemující okraje proximální části falešného lumen jsou tromby (T). B. V rekonstruovaném CT zobrazení metodou „volume rendering“ je evidentní disekce aneurysmatu ascendentní aorty s natržením aortální adventicie a penetrací do levé síně (šipka).
Pacient byl předán na kardiochirurgický operační sál, kde byla úspěšně provedena Bentallova operace (náhrada aortální chlopně mechanickou protézou, náhrada kořene a ascendentní aorty s reimplantací koronárních tepen) (obrázek 3). Následný pooperační průběh byl bez komplikací, pacient byl propuštěn do domácího ošetřování.
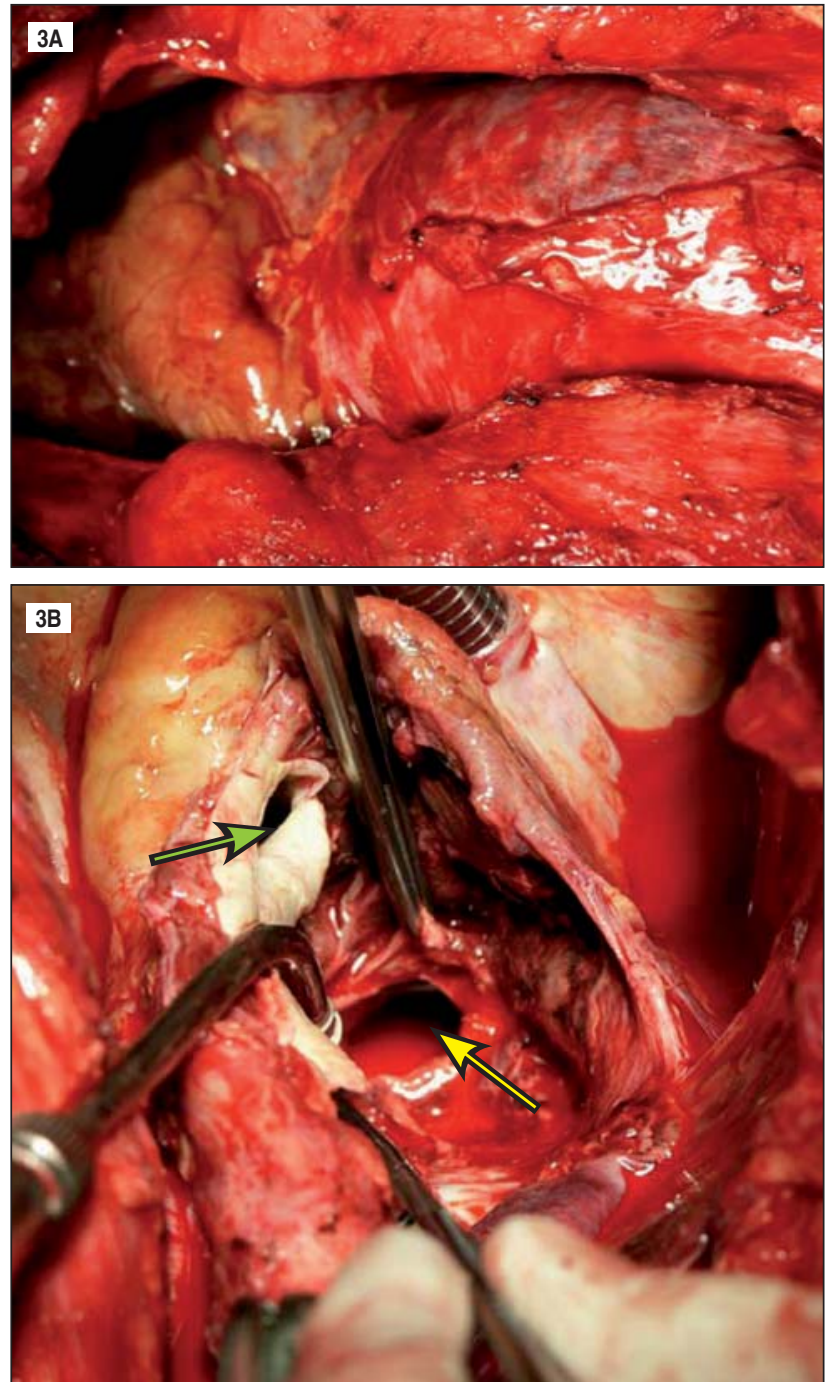

Obr. 3 Operační nález

A. $Z$ podélné sternotomie je uprostřed patrné aneurysma ascendentní aorty (pohled do operačního pole $z$ pozice anesteziologa).

B. Pohled do nepravého lumen s patrným penetračním otvorem do levé síně (žlutá šipka). Pravé lumen aorty je komprimováno odsávačem (zelená šipka). 